\title{
A checklist of Egyptian fungi: II. Glomeromycota
}

\author{
Nafady NA ${ }^{1^{*}}$, Abdel-Azeem AM $^{2}$ and Salem FM $^{2}$ \\ ${ }^{1}$ Botany and Microbiology Department, Faculty of Science, Assuit University, Assiut 71516, Egypt- \\ niviennafady@aun.edu.eg \\ ${ }^{2}$ Botany Department, Faculty of Science, Suez Canal University, Ismailia 41522, Egypt- \\ ahmed_abdelazeem@science.suez.edu.eg,fatmasalem@rocketmail.com
}

Nafady NA, Abdel-Azeem AM, Salem FM 2016 - A checklist of Egyptian fungi: II. Glomeromycota. Microbial Biosystems 1(1), 40-49

\begin{abstract}
Information about arbuscular mycorrhizal fungi (AMF) was abstracted based on an intensive search of publications, thesis, and preliminary annotated checklists and compilations. By screening all available sources of information, it was possible to report forty-eight taxa belonging to one class (Glomeromycetes), four orders (Archaeosporales, Diversisporales, Glomerales and Paraglomerales) and six families (Acaulosporaceae, Archaeosporaceae, Entrophosporaceae, Gigasporaceae, Glomeraceae and Pacisporaceae). Order Glomerales accommodates the greatest range of species (28 species), the order Archaeosporales and Paraglomerales accommodate the lowest range (one species each).
\end{abstract}

Key words - AM fungi - checklist - Egypt - Glomus - mycorrhiza - Saint Katherine

\section{Introduction}

The arbuscular mycorrhizal (AM) symbiosis is the most widespread on earth and is defined as the association between the fungi of the phylum Glomeromycota (Schüßler et al. 2001) and most of the terrestrial species ranging from thallophytes to Angiosperms. The morphology of the fungus colonizing plant root tissues is highly elaborated in AM symbiosis. In natural communities, approximately $80 \%$ of higher plants were obligately dependent upon fungal associates. AM fungi are believed to be disseminated intercontinentally prior to continental drift, as supported by fossil records of earlier plants (Berch 1986; Stubblefield et al. 1987; Remy et al. 1994).

Molecular data used by Schüßler et al. (2001) to establish the relationships among arbuscular mycorrhizal fungi and between arbuscular mycorrhizal fungi and other fungi. The group of arbuscular mycorrhizal fungi was elevated to the level of phylum Glomeromycota, which was shown to be as distinct from other fungi as the Ascomycota or from the Basidiomycota.

Eight genera include approximately 150 species of arbuscular mycorrhizal fungi have been recognized based mainly on morphological characteristics of asexual spores, although molecular methods and various biochemical parameters are now being used in systematic studies (Schüßler \& Walker 2010).

In Egypt, the pioneering work of Mostafa $(1938)$ and Sabet $(1939,1940,1945)$ is now accepted as the starting point of research on Egyptian Glomeromycota. These studies were followed by many other investigations concerned mainly with the ecology and physiology of

Submitted 22 October 2016, Accepted 8 December 2016, Published online 10 December $2016 \quad 40$ Corresponding Author: Nafady NA - e-mail - niviennafady@aun.edu.eg

This is an open access article distributed under the terms of the Creative Commons Attribution License, which permits unrestricted use, distribution, and reproduction in any medium, provided the original author and source are credited. 
endomycorrhizas in Egypt. However, taxonomic studies on Egyptian Glomeromycota are limited, and had never been the sole target of any study until Fares (1986) conducted a survey of AM, followed by Agwa (1990) and Nafady (2011) on mycorrhizas and nodulation in some Egyptian plants.

Checklists are important tools in biodiversity, taxonomy, systematics and conservation (Söderström et al. 2007, 2008; Abdel-Azeem and Salem 2013). In spite of that, several important areas lack recent checklists, including Egypt. For Egypt, only very few comprehensive assessments of local fungi have been published (e.g. El-Abyad and Abu-Taleb 1993; El-Abyad 1997; Abdel-Azeem 2010; Moustafa \& Abdel-Azeem 2011; Abdel-Azeem and Salem 2013).

Values of relative species richness of different systematic and ecological groups in Egypt compared to values of the same groups worldwide, show that our knowledge of Egyptian Glomeromycota is fragmentarym very rare and limited because may be Egyptian mycologists are not interested to study the taxonomy of Glomeromycota and this group ovderlooked during their studies (Abdel-Azeem 2010).

Following a recent publication on the assessment of total fungi in Egypt (Abdel-Azeem 2010, Abdel-Azeem and Salem 2013), this paper continues to close the gaps in knowledge on the fungal diversity of Egypt by providing a comprehensive checklist of Glomeromycotan fungi.

\section{Materials and methods}

Egypt is located in the extreme Northeast of Africa. The desert covers more than 90 percent of Egypt and can be divided into 4 major regions: The Nile Valley and Delta, Western Desert, Eastern Desert and Sinai Peninsula (Zahran and Willis 2009). The Nile River flows north through Egypt and into the Mediterranean Sea. The country has no effective rainfall except in a narrow band along the northern coast. Consequently, Egypt has only one main source of water supply, the Nile. The climate in Egypt is generally moderate; it is mostly hot or warm during the day, and cool at night. In the coastal regions, daytime average temperatures range between a minimum $14^{\circ} \mathrm{C}$ in winter and maximum $30^{\circ} \mathrm{C}$ in summer. In deserts the temperatures vary considerably, especially in summer; when they may range from $7^{\circ} \mathrm{C}$ at night, to $52^{\circ} \mathrm{C}$ during the day (Zahran and Willis 2009).

This study has undergone to report the most arbuscular mycorrhizal fungi in Egypt. So, this checklist has been compiled based on an intensive search of literatures and thesis. Nomenclature and authors names are according to the Schüßler's (http://www.amfphylogeny.com/) and Blaszkowski' websites (http://www.zor.zut.edu.pl/Glomeromycota/index.html) which reports a continually updated listing of species, genera, families, and orders in the phylum.

\section{Data Collection}

The species listed here were compiled mainly from the studies of Fares (1986), Mankarios and Abdel-Fattah (1994), Agwa (1990, 2000), Agwa and AbdelFatah (2002), Agwa and Al-Sodani (2003), Abdel-Azeem et al. (2007), El-Zayat et al. (2007), Abdel-Moneim and Abdel-Azeem (2009), Abdel-Azeem (2010), Mansour (2010), Nafady (2011) and Blaszkowski et al. $(2008,2010,2015)$.

\section{Results}

Forty-eight species of arbuscular mycorrhizal fungi including 12 genera, 6 families, 4 orders and 1 class are reported in this list of which AM fungi isolated from different localities in Egypt (Table 1). 
Table 1 Taxonomic ranks of Egyptian Glomeromycota

\begin{tabular}{|c|c|c|}
\hline Orders & Families & Genera \\
\hline Glomerales & Glomeraceae & $\begin{array}{l}\text { Dominikia (1) } \\
\text { Funneliformis (7) } \\
\text { Glomus (14) } \\
\text { Rhizophagus (4) } \\
\text { Sclerocystis (2) }\end{array}$ \\
\hline Diversisporales & $\begin{array}{l}\text { Gigasporaceae } \\
\text { Acaulosporaceae } \\
\text { Pacisporaceae }\end{array}$ & $\begin{array}{l}\text { Gigaspora (2) } \\
\text { Scutellospora (5) } \\
\text { Acaulospora (8) } \\
\text { Entrophospora (1) } \\
\text { Pacispora (2) }\end{array}$ \\
\hline Paraglomerales & Paraglomeraceae & Paraglomus (1) \\
\hline Archaeosporales & Archaeosporaceae & Archaeospora (1) \\
\hline
\end{tabular}

\section{Checklist of Glomeromycotan fungi reported in Egypt}

The genera and species are given in alphabetical order, with information on the area of Egypt where these the former were reported.

\section{Kingdom: Fungi}

Phylum: Glomeromycota

Class: Glomeromycetes

Order 1: Glomerales

Family 1: Glomeraceae (Figure 1)

1. Dominikia duoreactiva Błaszk., Goralska \& Chwat, Reported from sand dunes of Giftung Island by Blaszkowski et al. (2015).

2. Funneliformis africanum (Błaszk. \& Kovács) C. Walker \& A. Schüßler Synonym: Glomus africanum Błaszk. \& Kovács Reported from sand dunes of Giftung Island by Blaszkowski et al. (2010).

3. Funneliformis caledonium (Nicolson \& Gerd.) Walker \& Schüßler Synonym: Glomus caledonium (Nicolson \& Gerd.) Trappe \& Gerd.

Reported from three deltaic Governorrates by Mankarios and Abdel-Fattah (1994).

\section{Funneliformis coronatum (Giovann.) C. Walker \& Schuessler}

Synonym: Glomus coronatum Giovann.

Reported from Wadi Al-Alaqi protected area by El-Zayat et al. (2007), Ismailia Governorate by Baraka et al. (2012) and El-Menofia Governorate by Sabet et al. (2013).

5. Funneliformis geosporum (Nicolson \& Gerd.) Walker \& Schuessler Synonym: Glomus geosporum (Nicol. \& Gerd.) Walker

Reported from desert soil of Wadi Al-Assuity Protected area and reclaimed soil of AlGhoryb at Assiut Governorate by Nafady (2011).

6. Funneliformis mosseae (Nicolson \& Gerd.) Walker \& Schüßler Synonym: Glomus mosseae (Nicol. \& Gerd.) Gerd. \& Trappe 
Reported from three deltaic Governorrates by Mankarios and Abdel-Fattah (1994), cultivated soil, Bahr El-Baqar at Port Said Governorate by Abdel-Azeem et al. (2007), cultivated soil of Al-Wasta, reclaimed soil of Al-Ghoryb and desert soil of Wadi Al-Assuity Protected area at Assiut Governorate by Nafady (2011).

7. Funneliformis verruculosum (Błaszk.) Walker \& Schüßler Synonym: Glomus verruculosum Błaszk.

Reported from desert soil at North Sinai by Mansour (2010).

8. Funneliformis xanthium (Błaszk., Blanke, Renker \& Buscot) C. Walker \& Schuessler

Synonym: Glomus xanthium Blaszk., Blanke, Renker \& Buscot

Reported from cultivated soil of Al-Wasta at Assiut Governorate by Nafady (2011).

9. Glomus aggregatum Schenck \& Smith emend. Koske

Reported from desert soil of Wadi Al-Assuity Protected area at Assiut Governorate by Nafady (2011).

10. Glomus antarcticum Cabello

Reported from cultivated soil of Al-Wasta at Assiut Governorate by Nafady (2011).

11. Glomus caesaris Sieverd. \& Oehl

Reported from cultivated soil of Al-Wasta at Assiut Governorate by Nafady (2011).

12. Glomus constrictum Trappe

Reported from desert soil of Wadi Al-Assuity Protected area and reclaimed soil of AlGhoryb at Assiut Governorate by Nafady (2011).

13. Glomus diaphanum Morton \& Walker

Reported from Ismailia Governorate by Sabet et al. (2013).

14. Glomus etunicatum Becker \& Gerd

Reported from cultivated soil, Bahr El-Baqar at Port Said Governorate by Abdel-Azeem et al. (2007) and at Ismailia Governorate by Baraka et al. (2012).

15. Glomus fuegianum (Speg.) Trappe \& Gerd.

Reported from cultivated soil of Al-Wasta at Assiut Governorate by Nafady (2011).

16. Glomus invermaium Hall

Reported from Saint Katherine protected area by Abdel-Moneim and Abdel-Azeem (2009) and from Ismailia Governorate by Baraka et al. (2012).

17. Glomus lamellosum Dalpé, Koske \& Tews

Reported from reclaimed soil of Al-Ghoryb at Assiut Governorate by Nafady (2011).

18. Glomus monosporum Gerd. \& Trappe

Reported from three deltaic Governorrates by Mankarios and Abdel-Fattah (1994) and cultivated soil at Dakhlia Governorate by Abdel-Fattah (2001). 
19. Glomus sinosum (Gerd. \& B.K. Bakshi) R.T. Almeida \& N.C. Schenck Reported from cultivated soil, Bahr El-Baqar at Port Said Governorate by Abdel-Azeem et al. (2007).

20. Glomus trimurales Koske \& Halvorson

Reported from cultivated soil of Al-Wasta and reclaimed soil of Al-Ghoryb at Assiut Governorate by Nafady (2011).

21. Glomus versiforme (Karsten) Berch

Reported from cultivated soil of Al-Wasta and reclaimed soil of Al-Ghoryb at Assiut Governorate by Nafady (2011).

22. Glomus viscosum Nicolson

Reported from Ismailia Governorrate by Baraka et al. 2012.

23. Rhizophagus clarus (Nicolson \& Schenck) Walker \& Schüßler Synonym: Glomus clarum Nicolson \& Schenck

Reported from cultivated soil, Bahr El-Baqar cultivated area at Port Said Governorate by Abdel-Azeem et al. (2007), desert soil of Wadi Al-Assuity Protected area and cultivated soil of Al-Wasta at Assiut Governorate by Nafady (2011).

24. Rhizophagus fasciculatus (Thaxt.) Walker \& Schüßler Synonym: Glomus fasiculatum Thaxt.

Reported from from three deltaic Governorrates by Mankarios and Abdel-Fattah (1994), cultivated soil at Dakhlia Governorate by Abdel-Fattah (2001).

25. Rhizophagus intraradics (Schenck \& Sm.) Walker \& Schüßler Synonym: Glomus intraradices Schenck\& Sm.

Reported from cultivated soil of Al-Wasta at Assiut Governorate by Nafady (2011), Ismailia Governorrate by Baraka et al. 2012 and Behira Governorate by Sabet et al. 2013.

26. Rhizophagus irregularis (Błaszk., Wubet, Renker \& Buscot) C. Walker \& A. Schüßle

Synonym: Glomus irregulare

Reported from sand dunes of Giftung Island by Blaszkowski et al. (2008).

27. Sclerocystis clavispora Trappe

Synonym: Glomus clavisporum Almeida \& N.C. Schenck )

Reported from Saint Katherine protected area by Abdel-Moneim and Abdel-Azeem (2009).

28. Sclerocystis sinuosa Gerd. \& Bakshi

Synonym: Glomus sinuosum (Gerd. \& Bakshi) Almeida \& Schenck

Reported from cultivated soil, Bahr El-Baqar cultivated area at Port Said Governorate by Abdel-Azeem et al. (2007).

\section{Order 2 : Diversisporales}

Family 2: Gigasporaceae

29. Gigaspora gigantean (Nicol. \& Gerd.) Gerd. \& Trappe

Basionym: Endogone gigantea Nicolson \& Gerd.

Reported from cultivated soil of Al-Wasta at Assiut Governorate by Nafady (2011). 


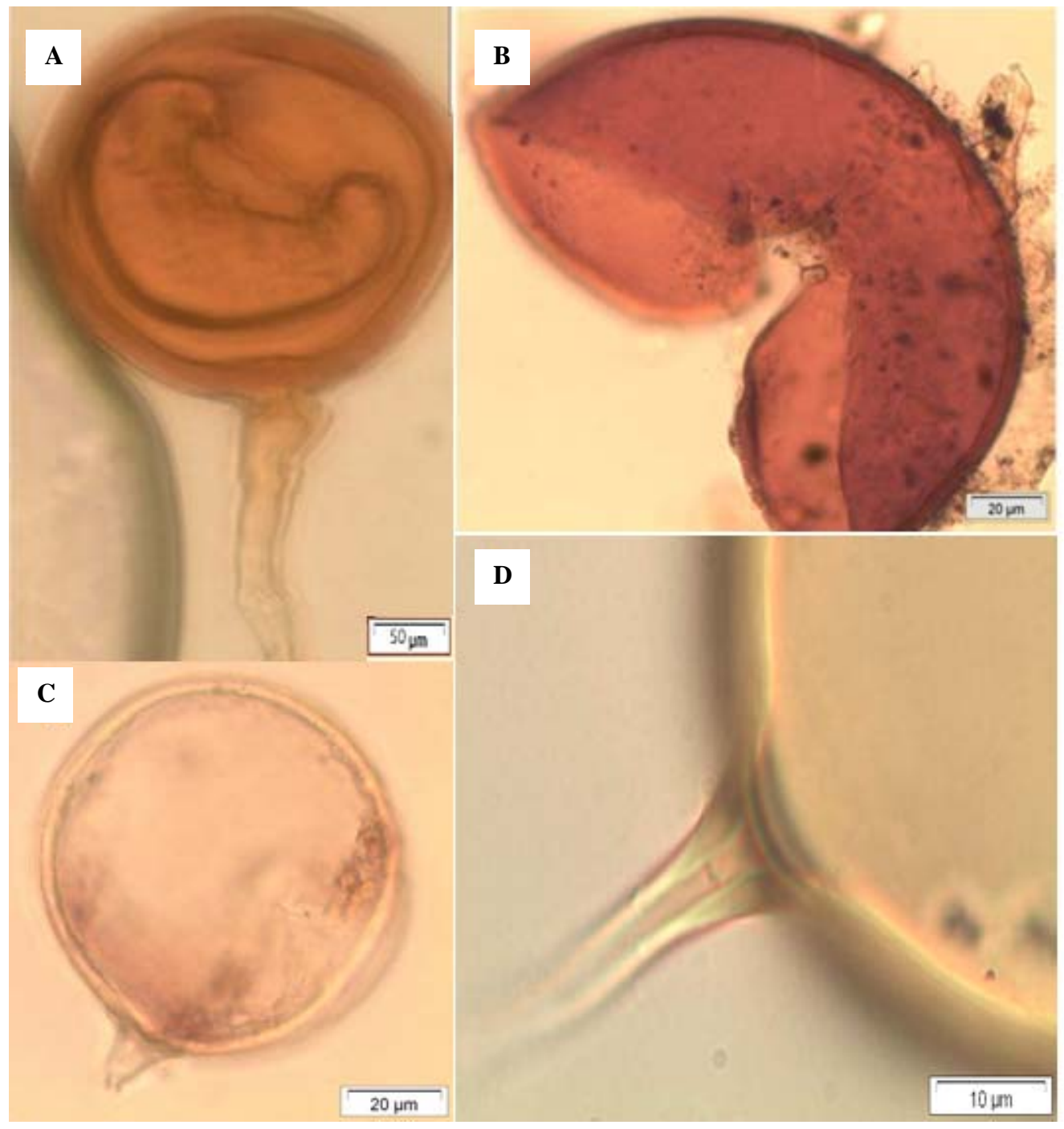

Fig. 1- Mature spores of Funneliformis geosporum (A), Glomus constrictum (B), Funneliformis mosseae (C) and Rhizophagus clarus (D).

30. Gigaspora margarita Becker \& Hall

Reported from cultivated soil, Bahr El-Baqar cultivated area at Port Said Governorate by Abdel-Azeem et al. (2007), desert soil of Wadi Al-Assuity Protected area at Assiut Governorate by Nafady (2011).

31. Scutellospora armeniaca Blaszk.

Synonym: Cetraspora armeniaca Oehl, Souza \& Sieverd.

Reported from cultivated soil of Al-Wasta at Assiut Governorate by Nafady (2011).

32. Scutellospora calospora (Nicolson \& Gerd.) Walker \& Sanders

Synonym: Gigaspora calospora Nicolson \& Gerd.

Reported from cultivated soil of Al-Wasta at Assiut Governorate by Nafady (2011). 
33. Scutellospora fulgida Koske \& Walker

Reported from cultivated soil of Al-Wasta at Assiut Governorate by Nafady (2011).

34. Scutellospora persica (Koske \& Walker) Walker \& Sanders

Reported from reclaimed soil of Al-Ghoryb at Assiut Governorate by Nafady (2011).

35. Scutellospora reticulate (Koske, Mill. \& Walker) Walker \& Sanders

Reported from cultivated soil of Al-Wasta at Assiut Governorate by Nafady (2011).

\section{Family 3: Acaulosporaceae (Figure 2)}

36. Acaulospora laevis Gerd. \& Trappe

Reported from three deltaic Governorrates by Mankarios and Abdel-Fattah (1994), cultivated soil of Al-Wasta and reclaimed soil of Al-Ghoryb at Assiut Governorate by Nafady (2011).

37. Acaulospora bireticulata Rothwell \& Trappe

Reported from desert soil of Wadi Al-Assuity Protected area at Assiut Governorate by Nafady (2011).

38. Acaulospora capsicula Blaszk.

Reported from reclaimed soil of Al-Ghoryb and desert soil of Wadi Al-Assuity Protected area at Assiut Governorate by Nafady (2011).

39. Acaulospora koskei Blaszk.

Reported from reclaimed soil of Al-Ghoryb at Assiut Governorate by Nafady (2011).

40. Acaulospora rehmii Sieverd. \& Toro

Reported from cultivated soil of Al-Wasta at Assiut Governorate by Nafady (2011).

41. Acaulospora splendid Sieverd., Chaverri \& Rojas

Reported from reclaimed soil of Al-Ghoryb and cultivated soil of Al-Wasta at Assiut Governorate by Nafady (2011).

42. Acaulospora thomii Blaszk.

Reported from reclaimed soil of Al-Ghoryb and cultivated soil of Al-Wasta at Assiut Governorate by Nafady (2011).

43. Acaulospora tuberculata Janos \& Trappe

Reported from cultivated soil of Al-Wasta, reclaimed soil of Al-Ghoryb and desert soil of Wadi Al-Assuity Protected area at Assiut Governorate by Nafady (2011).

44. Entrophospora infrequens (I.R. Hall) R.N. Ames \& R.W. Schneid.

Reported from cultivated soil of Al-Wasta and reclaimed soil of Al-Ghoryb at Assiut Governorate by Nafady (2011).

Family 4: Pacisporaceae

45. Pacispora boliviana Sieverd. \& Oehl

Reported from cultivated soil of Al-Wasta at Assiut Governorate by Nafady (2011).

46. Pacispora franciscana Sieverd. \& Oehl

Reported from cultivated soil of Al-Wasta and reclaimed soil of Al-Ghoryb at Assiut Governorate by Nafady (2011). 


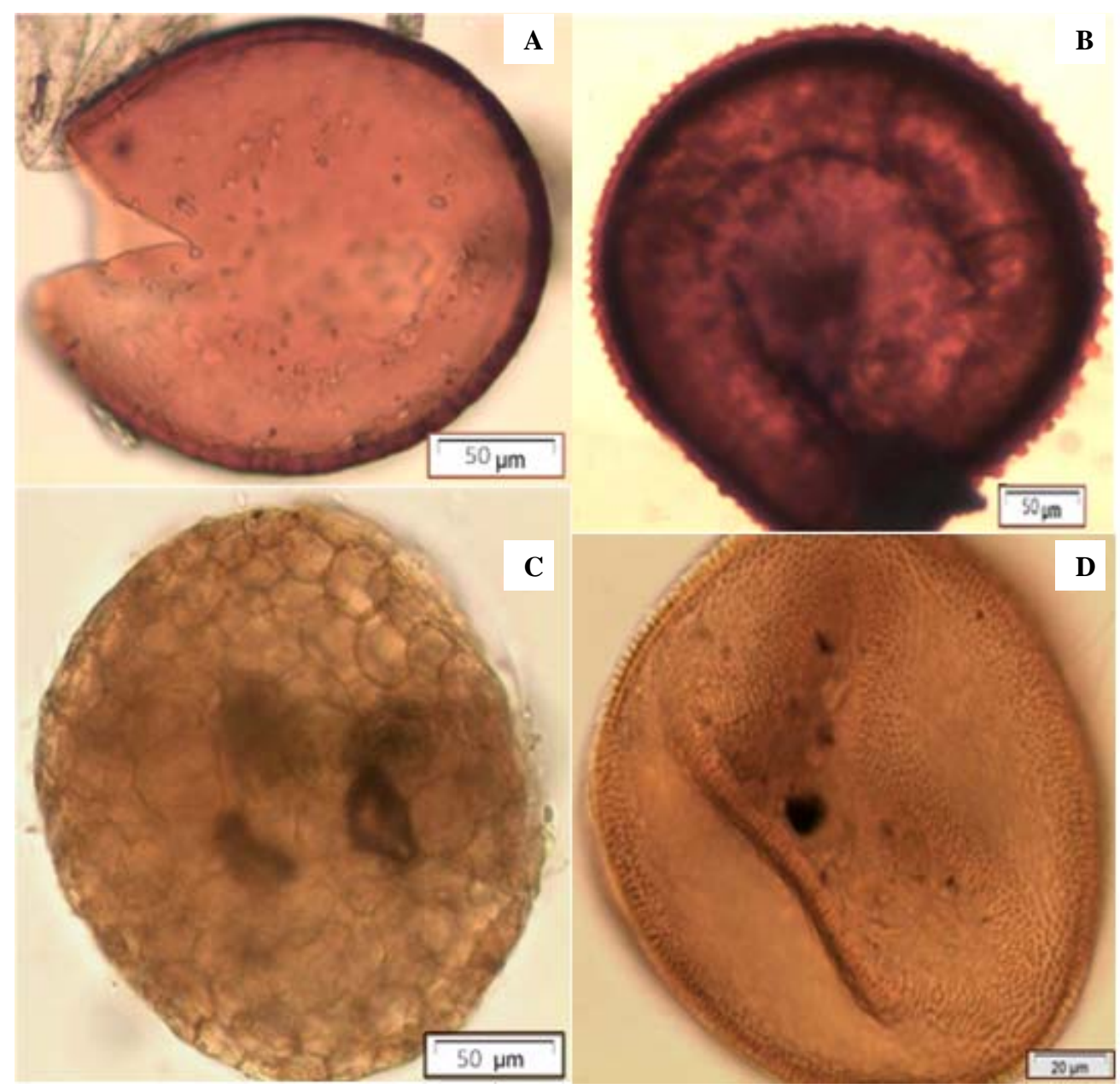

Fig. 2- Mature spores of Acaulospora capsicula (A), Acaulospora tuberculata (B), Acaulospora bireticulata (C) and Entrophospora infrequens (D).

Order 3: Paraglomerales

Family 5: Paraglomeraceae

47. Paraglomus occultum (Walker) Morton \& Redecker collected by Hamdy Agwa from unknow location in Egypt as mentioned by Morton \& Redecker (2001).

\section{Order 4 : Archaeosporales}

Family 6: Archaeosporaceae

48. Archaeospora trappei (Ames \& Linderman). Morton \& Redecker

Reported from cultivated soil of Al-Wasta and reclaimed soil of Al-Ghoryb at Assiut Governorate by Nafady (2011).

\section{References}

Abdel-Azeem A. M. 2010. The history, fungal biodiversity, conservation, and future perspectives for mycology in Egypt. IMA fungus 1(2): 123-142.

Abdel-Azeem A. M. and Salem F. M. 2013. A checklist of Egyptian fungi: I. Protozoan fungal analogues. Mycosphere 4(4): 794-807. 
Abdel-Azeem A. M., Abdel-Moneim T. S., Ibrahim M. E., Hassan M. A. A. and Saleh M.Y. 2007. Effect of long-term heavy metal contamination on diversity of terricolous fungi and nematodes in Egypt - a case study. Water, Air, and Soil Pollution 186: 233-254.

Abdel-Fattah G. M. 2001. Measurement of the viability of AM fungi colonized in roots using three different stains and its relation to growth and metabolic activities of soybean plants. Microbiological Research 156: 359-367.

Abdel-Moneim T. S. and Abdel-Azeem A. M. 2009. Operation Wallacea in Egypt. II- Diversity of arbuscular mycorrhizal fungi in different elevation wadis in Saint Katherine Protectorate, Egypt. Assiut University Journal of Botany 38: 55-74.

Agwa H. E. 1990. Vesicular arbuscular mycorrhizae and nodulation in some Egyptian plants. $\mathrm{PhD}$ thesis, Tanta University, Egypt.

Agwa H. E. 2000. Arbuscular mycorrhizal fungi (Glomales) in Egypt. I. A field survey of Arbuscular mycorrhizal fungi associated with medicinal plants and effect of inoculation on growth of some plants. African Journal of Mycology and Biotechnology 8: 1-12.

Agwa H. E. and Abdel-Fattah G. M. 2002. Arbuscular mycorrhizal fungi (Glomales) in Egypt II. An ecological view of some saline affected plants in the Deltatic Mediterranean coastal land. Acta Botanica Hungarica 44: 1-17.

Agwa H. E. and Al-Sodany Y. M. 2003. Arbuscular-mycorrhizal fungi (Glomales) in Egypt. III: Distribution and ecology in some plants in El-Omayed Biosphere Reserve. Egyptian Journal of Biology 5: 19-26.

Baraka M. A., Abd-Elmoneim T. S., Ramadan El-S. M. and Mohamed Alaa F. 2012. Biodiversity and Classification of Arbuscular Mycorrhizal Fungi (Glomales) in Ismailia Governorate. Agricultural Research Journal, Suez Canal University 12 (1): 83-90.

Berch S. M. 1986. Endogonaceae: taxonomy, specificity, fossil record, phylogeny. In: Mukerji KG, Singh VP. Frontiers in Applied Microbiology Vol. 2. Lucknow, India: Print House, 161-188.

Błaszkowski J., Chwat G., Góralska A., Ryszka P. and Kovács G. M. 2015. Two new genera, Dominikia and Kamienskia, and D. disticha sp. nov. in Glomeromycota. Nova Hedwigia, 100(1-2): 225-238.

Blaszkowski J., Czerniawska B., Wubet T., Schäfer T., Buscot F. and Renker C. 2008. Glomus irregulare, a new arbuscular mycorrhizal fungus in the Glomeromycota. Mycotaxon 106: 247-267.

Błaszkowski J., Kovács G. M., Balázs T. K., Orlowska E., Sadravi M., Wubet T. and Buscot F. 2010. Glomus africanum and G. iranicum, two new species of arbuscular mycorrhizal fungi (Glomeromycota). Mycologia 102 (6): 1450-1462.

El-Abyad M. S. 1997. Biodiversity of Fungal Biota in Egypt. Up-dated check-list. [Publication of National Biodiversity Unit No. 7.] Egyptian Environmental Affairs Agency.

El-Abyad M. S, and Abu-Taleb A. 1993. II-Soil Fungi. Ecology of fungal flora. In: Publication of National Biodiversity Unit. No. 1. Habitat Diversity: 237-262. Egyptian Environmental Affairs Agency, Egypt.

El-Zayat S. A., Abdel-Azeem A. M., Abdel-Moneim T. S. and Deyab A. S. 2007. Association of arbuscular mycorrhizal fungi in Southern Eastern Desert (Wadi El-Alaqi, biosphere reserve) Aswan, Egypt. El- Minia Science Bulletin 18: 158-182.

Fares C. A. 1986. Studies on vesicular arbuscular mycorrhizal in Egypt. M. Sc. Thesis, Fac. Agric., Ain Shams University, Egypt.

Mankarios A. T. and Abdel-Fattah G. M. 1994. Ecology of VA-mycorrhiza in Some Egyptian soils. Egyptian Journal of Botany 34: 135-152.

Mansour M. A. I. 2010. Endomycorrhizal fungi as a biocontrol mean of tomato-fusarial -wilt in North Sinai. MSc thesis, Faculty of Education, University of Suez Canal, Al-Arish, Egypt. 
Morton J. B. and Redecker D., 2001. Two new families of Glomales, Archaeosporaceae and Paraglomaceae, with two new genera Archaeospora and Paraglomus, based on concordant molecular and morphological characters. Mycologia 93(1): 181-195.

Mostafa M. A. 1938. Mycorrhiza in Tropaeolum majus L. and Phlox drummondii Hook. Ann. Bot. 2:481-490.

Moustafa, A. F. and Abdel-Azeem, A. M. 2011. An annotated check-list of Ascomycota reported from soil and other terricolous substrates in Egypt. Journal of Basic and Applied Mycology 2: $1-27$.

Nafady N. A. 2011. Biodiversity of Arbuscular Mycorrhizal Fungi in Assiut and their Application in Faba Bean Plants cultivated in Zn-Polluted Soil. PhD thesis, Assiut University, Egypt.

Remy W., Taylor T. N., Hass H. and Kerp H. 1994. Four hundred-million-year-old vesicular arbuscular mycorrhizae. Proceedings of the National Academy of Sciences 91(25): 1184111843.

Sabet K. K., Mansour M. S., El-Hadad S. A., Shaltout A. M. and Abeid S. E. 2013. Differentiation between Glomus species in Egyptian soil using fatty acid methyl ester profiles. Asian Journal of Plant Pathology 7(2): 60-73.

Sabet Y.S. 1939. Cotton mycorrhiza. Nature (London) 144: 37.

Sabet Y.S. 1940. Mycorrhizal habit in the date palm (Phoenix dactlylifera L.). Nature 145: 782.

Sabet Y.S. 1945. Reaction of Citrus mycorrhiza to manorial treatment. Proc. Egypt. Acad. Sci., 21-28.

Schüßler A. and Walker C. 2010. The Glomeromycota: a species list with new families and new genera. The Royal Botanic Garden Kew, Botanische Staatssammlung Munich, and Oregon State University.

Schüßler A., Schwarzott D. and Walker C. 2001. A new fungal phylum, the Glomeromycota: phylogeny and evolution. Mycological Research 105: 1413-1421.

Söderström L., Urmi E. and Váňa J. 2007. The distribution of Hepaticae and Anthocerotae in Europe and Macaronesia- Update 1-427. Cryptogamie, Bryologie 28, 299-350.

Söderström L., Hagborg A., von Konrat M. and Renner M. A. M. 2008. Early Land Plants Today: Liverwort checklist of checklists. Fieldiana, Botany, n.s. 47, 105-130.

Stubblefield S. P., Taylor T. N. and Trappe J. M. 1987. Vesicular-arbuscular mycorrhizae from the Triassic of Antarctica. American Journal of Botany 74(12): 1904-1911.

Zahran, M.A. and Willis, A.J. 2009. The Vegetation of Egypt. $2^{\text {nd }}$ Edition, Springer, Netherlands. 